Article

\title{
Fancy Schools for Fancy People: Risks and Rewards in Fieldwork Research Among the Low German Mennonites of Canada and Mexico
}

\author{
Robyn Sneath
}

Department of Education, The University of Oxford, Oxford OX1 2JD, UK; robynsneath@gmail.com

Received: 2 December 2018; Accepted: 19 December 2018; Published: 9 January 2019

\begin{abstract}
In the 1920s, conflict over schooling prompted the exodus of nearly 8000 Mennonites from the Canadian prairie provinces of Manitoba and Saskatchewan to Mexico and Paraguay; this is the largest voluntary exodus of a single people group in Canadian history. Mennonites-whose roots are found in the 1520s Reformation - are an Anabaptist, pacifist, isolationist ethnic, and religious minority group, and victims of a fledgling Canada's nation-building efforts. It is estimated that approximately 80,000 descendants of the original emigrants have subsequently returned to Canada, where tensions over schooling have persisted. The tensions-then, as now-are rooted in a fundamentally different understanding of the purposes of education-and it is this tension that interests me as an ethnographer and education researcher. My research is concerned with assessing attitudes towards education within the Low German Mennonite (LGM) community in both Canada and Mexico. Too often academic research is presented as a tidy finished product, with little insight shed into the messy, highly iterative process of data collection. The purpose of this article is to pull back the curtain and discuss the messiness of the process, including security risks involved with methodology, site selection, research participants, and gaining access to the community.
\end{abstract}

Keywords: education; religion; Mennonites; methodology; ethnography; fieldwork; Canada; Mexico; transnational; security

In the 1920s, conflict over schooling prompted the exodus of nearly 8000 conservative, Low German-speaking Mennonites (LGM) from the Canadian prairie provinces of Manitoba and Saskatchewan to Mexico and Paraguay; this is the largest voluntary exodus of a single people group in Canadian history (Ens 1994; Janzen 1990; Loewen 2013). Mennonites-whose roots are found in the 1520s Reformation-are an Anabaptist, non-resistant, isolationist ethnic and religious minority group, and, in this particular case, victims of a fledgling Canada's nation-building efforts (Ens 1994). It is estimated that approximately 80,000 descendants of the original emigrants have subsequently returned to Canada, where tensions over schooling have persisted (Loewen 2013). The tensions-then, as now-are rooted in a fundamentally different understanding of the purposes of education.

Though the content of my broader research agenda focuses explicitly on issues of religion, education, and security, the focus of this particular paper is on methodological issues arising from research within this relatively closed community. Too often, academic research is presented as a tidy finished product, with little insight shed into the messy, highly iterative process of data collection (Mills and Morton 2013). The purpose of this article is to pull back the curtain and discuss the messiness of the process, including challenges with methodology, site selection, research participants, and gaining access to the community. Education research among this ethno-religious minority group involved a number of security risks - or perceived risks—as well as challenges, and it is a discussion of these issues which shall occupy the bulk of the article. It is my contention that ethnographic research-time in the field-invariably poses risks to both researcher and researched, but that these risks are rarely 
considered within the broader framework of the finished research product. In this particular case, the security hazards encountered in the field had little to do with the community itself, rather it was peripheral, environmental, and political threats that influenced the research. These risks, in this case, were compounded by the fact that the research was multi-sited, necessitating a constant renegotiation of my position as researcher. This paper is based on fieldwork that I conducted among Mennonites in the Canadian prairie province of Manitoba and the northern Mexican state of Chihuahua between December 2013 and January 2016. It is based on visits to several schools, and roughly 70 interviews, conducted with students, parents of students, teachers, administrators, and school support staff.

'Low German Mennonite' has become common parlance to refer to those Mennonites whose first language is Low German, but it also connotes a host of unspoken markers of distinctive Otherness-living a life set apart from mainstream society, dressing differently, possessing a strong network of connections to other Low German Mennonites spread throughout the diaspora, and belonging to an imagined community (Anderson 1983) of fellow Low German-speaking Mennonites. While referring to the community by their vernacular is common practice (Loewen 2015), there are several sub-groups that fit under the LGM umbrella, including Altkolonier or Old Colony, which was known as Reinlaender from c. 1875-1920s (and is distinct from the Reinlaender Church that was established in the 1950s and which exists today in southern Ontario, southern Manitoba, and western Kansas, but which is not affiliated with the Old Colony), Sommerfelder, Bergthaler, Gemeinde Gottes, Kleine Gemeinde, and Evangelical Mennonite Mission Conference (EMMC) and Conferencia Mennonites in Mexico. These are all splinter groups who have broken off because of competing theologies. Old Colony represents the most conservative end of the LGM spectrum. Visible intra-group markers of difference- such as the use of horses and buggies as a mode of transportation ${ }^{1}$-are evident to outside observers, whereas other distinguishing features, like nuances in soteriology and eschatology, are less discernable.

The 'problem' as it were, in this particular case, is the schooling of LGM children in Canada and Mexico. The schooling practices of the most conservative elements of the LGM community have remained largely unchanged since they immigrated to Manitoba from Russia in the 1870s-it is the schooling practices of the world around them which have changed dramatically, thereby rendering LGM schooling deviant. The 'problem' is also that historically, schools have served as the primary site through which LGM children have been initiated into the language, religion, culture, and worldview of their closed communities; however, as schools respond and adapt to modern influences-introduced largely by significant transnational connections-the schools of the LGM community have increasingly become sites where the very things they have sought to preserve are the things they now destroy.

As the first to argue that LGM schools are the key site through which to examine the unresolved tension of adapting to elements of the outside world (introduced by transnationalism) while concurrently maintaining what is essential about their faith, culture, and tradition-this work contributes not only to the field of Mennonite Studies, but to conversations about the relationship between religion and education. As Stambach (2000) argues, 'schools are often pivotal social institutions around which the configuration of society as a whole is imagined, contested, and transformed, and that schooling provides one of the clearest institutions for observing debates about culture, generation, gender, and history' (Stambach 2000, p. 3). As the first of its kind-an exploration of a world often closed to outsiders-my work provides an examination of LGM schooling practices—in its many and varied iterations. While others have touched on aspects of the schooling practices (Leonard 1971; Hedges 1996; Crocker 2013; Good Gingrich 2016; Saunders-Currie 2017), my work is an explicit and holistic assessment of their schools and the first to examine the effects of transnationalism on LGM schooling practices. In Discipline and Punish (1977), Foucault uses the prison to illuminate previously unidentified aspects of modern life, issues which are most evident in the setting of the prison but

1 This is still the common practice among Old Colony Mennonites in Bolivia, and some remote parts of Mexico. 
with implications across the breadth of modern society. In the same vein, I argue that for the LGM community, the social institution of the school serves a similarly illustrative function, revealing a conflict that is most clearly expressed in the school setting but which exists across the spectrum of LGM lived experience.

By rooting the current practices carefully within the context of their history of migration and past tensions with the Canadian government over schools, I demonstrate that contemporary practices are an extension of the ongoing conflict over their interpretation of their collective past. Additionally, by situating the current practices in Canada and Mexico within the framework of their past, I have shown that now, as then, LGM schools serve to sustain a commitment to a particular vision for society-and that the shape and content of each different type of school creates and sustains often drastically different iterations of society, even within a community that to the outside observer may be perceived as relatively homogenous.

The choices made by families about their children's schooling is always a manifestation of multiple factors, a mix of ideological, pragmatic, and economic impulses resulting in a decision that invariably involves some degree of ambivalence. In Canada, for some families sending their children to public schools is economically motivated, a commitment to a different future than their own present. But for other families, sending their children to public schools is simply a matter of getting by, the least expensive, most expedient means of educating their children and a necessary compromise of life in Canada.

Ultimately, the decisions families make about their children's schooling determines not only their individual futures, but also the fate of the community. As Schmiedehaus, an early scholar of Old Colony Mennonites, wrote 'Die Schule bestimmt das Schicksal der Altkolonie, ${ }^{2}$-'the school determines the fate of the Old Colony' (Schmiedehaus 1982, p. 129). Schmiedehaus was echoing the claim made by one of the central Old Colony leaders, Aeltester Isaak M. Dyck (1889-1969), who, in his memoir of emigration from Canada to Mexico, Auswanderung von Kanada nach Mexiko, presciently noted that 'the school of today represents the church of tomorrow' (Dyck 1995, p. 40, translation mine). ${ }^{3}$ It is a reciprocal relationship of influence-the community influences the shape and content of the schools, and then the schools - as they shape the beliefs and values of their students-in turn shape the future of the communities to which the young people belong.

What I propose is a dialectical relationship between transnational influences and LGM perceptions about the role schools ought to play in preserving the group's tradition. Transnationalism, in this instance, engenders a particular approach to education and sustains the commitment to their specific purposes of education. Sociologist Urry (2000) argues that it is not only humans who move between states and societies, but that non-animate movers such as images, information, and objects-and I would add institutions, in this case, the school-are all mobile and 'hence produce and reproduce social life and cultural forms' (Urry 2000, p. 49). For Old Colony Mennonites, this has been especially true, as they have recreated their schools in each new country of settlement, with the school historically being the first common building constructed in a community (Francis 1955; Peters 1985).

Mennonites, a conservative Protestant ethnic and religious minority group, originated in Europe in the 1520s. From the earliest decades, there have been two dominant strands-the Swiss/South German strand, and the Dutch/northern German strand, and it is the Dutch element from which the Mennonites of this particular study are descended. And though Menno Simons (1496-1561), a Dutch ex-Catholic priest, was not the founder of the movement, he was an influential early leader under whom the disparate pacifist-inclined Anabaptist groups began to consolidate and it is from him that Mennonites derive their name.

2 'The schools determine the fate of the Old Colony' (translation mine, in Schmiedehaus (1982, p. 129)).

The version of the memoir I use is the most recent one, published in 1995 (with slight amendments), and which I translated in 2005 from High German into English as a contract translator. It is an unpublished translation. The original memoir was published in 1970, and subsequently in 1971 and was split into two volumes. I rely on the first here, as it focuses on the migration period. 
Because of religious persecution over the course of a few centuries, northern European Mennonites migrated from the Netherlands (mostly Flanders, but also Friesland) to Poland (near present-day Gdansk) to Russia before immigrating to Canada in the 1870s (Urry 2006). The designation 'Old Colony Mennonite' refers to the fact that this particular group of Mennonites were the first to migrate to Russia ${ }^{4}$ and establish the Chortitz colony, which became known as the 'Old Colony.' Over time, the term has acquired an increasingly religious connotation and now refers to a particular Mennonite denomination (Ens 1994). Conflict with the Russian authorities in the late nineteenth century over issues of schooling and exemption from military service prompted the exodus to the Canadian prairies in Manitoba in the 1870s, where the Mennonites settled in two primary blocs—-the East and West Reserves.

During the second generation of Mennonite settlement in Canada, the provincial governments of Manitoba and Saskatchewan introduced several pieces of legislation which sought to loosen the boundaries between the Mennonites and their neighbours, in an attempt to assimilate the polyglot immigrants of the prairies into a common Anglo-British culture, including the 1890 Manitoba Schools Act, 1907 legislation mandating that the Union Jack flag be flown outside all schools in Manitoba; and the 1916 Schools Act (Francis 1955; Ens 1994). In fact, the provinces went so far as to expropriate Mennonite land, erect public schools, hire non-Mennonite teachers, and demand attendance in an attempt to acculturate the non-conformists (Janzen 1990). This attempted coercion only served to further alienate the isolationist agriculturalists and spurred them on to emigration (Ens 1994). In several instances, the Mennonites refused to comply, resulting in fines and imprisonment for parents and village leaders (Janzen 1990). By the 1920s-when post-WWI-anti-German sentiment was high-the situation had deteriorated to such an extent that the emigration seemed the best option.

In the 1920s, a third of Manitoba's of Old Colonists relocated from Canada to Mexico (Ens 1994). And while tens of thousands have returned to Canada (ca. 80,000 over the past 90 years, Loewen 2013), thousands have left Mexico in favour of more remote locales of Bolivia and Belize in order to avoid what they perceive as the encroaching secular influence in their communities.

The Low German Mennonite diaspora today numbers approximately 300,000 (Krahn and Sawatzky 1990; Loewen 2015) and unlike the host nations in which Dietsche find themselves, theirs is a relatively closed community organized almost exclusively around the Jemeent, the Low German term for the congregation, the Gemeinschaft, not the Gesellschaft (Tönnies 2001; Weber 1921; Loewen 2015), a network of affective relations based around a central governing axis-the Church.

The sacred/secular divide, espoused by Weber (1921) and embraced by Geertz (1973) in many ways feels like an obsolete relic of modernism, and is completely foreign to the LGM world. Religion scholar Robert Orsi emphasizes that religion permeates throughout the entire range of lived experience, including in its most pedestrian iterations (Orsi 1997), which for the Dietsche community includes such seemingly mundane phenomena as the range of acceptable free play activities available to children during school recess.

For Low German Mennonites, schooling has historically served as the primary locus through which their language, faith, and worldview have been transmitted and these goals have often conflicted directly with concepts of schooling as a vehicle through which to promote autonomy, social mobility, and loyalty to the state. And while the Canadian federal government-through Minister of Agriculture John Lowe-initially promised the Mennonites freedom to conduct their schools as they saw fit, between 1890 and 1920 the provincial governments of Manitoba and Saskatchewan introduced legislation that increasingly curtailed the religious and linguistic freedoms enjoyed by the Mennonites in their schools (Francis 1955; Janzen 1990; Ens 1994). What the Mennonites may not have realized was that, according to the British North America Act of 1867, schooling was regulated provincially in Canada, not federally (Gregor and Wilson 1984; Bruno-Jofre 1993). The situation deteriorated to such an extent that, in the 1920s, the Mennonites emigrated en masse to Mexico, where Alvaro Obregon's

4 Present-day Ukraine. 
government promised them the right to exercise their religious freedom in their schools-a promise which has been largely kept, other than a brief hiatus in 1935 (Schmiedehaus 1982).

Old Colony Mennonite village schools in Mexico are conducted in a manner that has changed little since the Mennonites were in Russia in the nineteenth century (Hedges 1996). Schoolhouses are single-room, taught by a man from the community, children attend for six to seven years, and the focus of the curriculum is largely religious with the Bible and catechism serving as the primary texts. The language of instruction is High German, a language reserved for school and church. Low German, largely considered to be an oral dialect, comprises the language of home and commerce. The focus is on memorization of religious texts, not reading comprehension, and subjects like science, geography, history, and Spanish are all dismissed as worldly. The schools of the other Mennonite denominations on the colonies range in their level of progressiveness-with Old Colony Komitee Schools, Kleine Gemeinde and Gemeinde Gottes schools in the middle and the Conferencia offering a full university preparatory program.

In Canada, most LGM immigrant families send their children to public elementary schools simply because of economic constraints-it is free. In southern Manitoba, there are a few small unaccredited LGM independent schools that emphasize separation from the world, and there are a number of families who have opted to homeschool their children. Most families do not send their children to school past Grade Eight even though the legal school leaving age in Manitoba is 18 (Manitoba Schools Act 2013).

Most LGM communities practice voluntary social exclusion (Good Gingrich 2016); gaining access was a gradual process which was ultimately achieved by emphasizing my shared lineage. My interest in this community and in their experiences with education arose from a personal connection; my grandfather participated in the 1922 migration to Mexico and his father was one of the first schoolteachers in Mexico. My grandfather, however, left the community as an adolescent, and thus, my connection to the community was more symbolic than real. I was familiar with their schooling practices and curious about how their frequent transnational migrations shaped their schooling experiences in each respective country. My ability to communicate in High German, and my faltering attempts at Low German, also aided my entry into the community.

Although the 'counter-terrorist classroom' (Gearon 2013) is a recent concept, the notion of using classrooms and schools to instill particular cultural values into the nation's young is hardly new. As Ghosh et al. (2016) note, education has often been used to counter values that would threaten liberal democratic society. Interestingly, Ramirez and Boli (1987) argue that using schools to further a political, assimilationist, nationalist agenda became ubiquitous in the late nineteenth century in the West. In their work on the evolution of mass schooling throughout the long nineteenth century, they argue that European nation states began to construct national school systems in an attempt to create 'a unified national polity', where the individual was the primary social actor, and one's principal loyalty lay with the state, rather than with one's family, church, or ethnicity (Ramirez and Boli 1987). I would argue that the counter-terrorist classroom is an extension of the same underlying impulse - that of using schools to cultivate a desired polis, ready to defend the nation against any perceived threat-whether terrorists today or Germans during WWI.

In fact, during the height of tension surrounding the Mennonite schools question, the goal was indeed to inspire loyalty to the empire, as then Manitoba Premier Roblin stated (in 1907), 'what we need is to get the youth filled with the traditions of the British flag and then, when they are men ... they will be able to defend it' (Roblin, quoted in Francis 1955, p. 174). This association between the flag and militarism was clearly sensed by Aeltester Isaak M. Dyck in his memoir: 'it was impossible for us to allow our children to be raised under the flag and under the enthusiastic expression of military zeal' (Dyck 1995, p. 40, translation mine).

The task of the ethnographer, according to Clifford Geertz, 'is first to grasp and then to render' (Geertz 1973, p. 10). Geertz (1973, p. 24) likens the ethnographic process to a conversation, one in which it is the responsibility of the researcher to learn to listen, but also to observe, with the ultimate goal of being able to decipher 'what it is ... that ... is getting said' (Geertz 1973, p. 10). This paper elaborates 
on this essential concept, clarifying how it is that I sought to understand, interpret and ultimately communicate what was gleaned from dozens of conversations in schools, churches, and around kitchen tables in both Canada and Mexico.

What constitutes ethnography, as both a method and mode of analysis, varies widely in the literature. Cultural anthropologists of the early-mid-twentieth century defined ethnography as a methodology (Malinowski 1922; Mead 1928; Evans-Pritchard 1940), and it was gradually adopted by the social sciences because of its potential to provide a holistic and highly specific account of the topic or people under investigation. Initially, ethnography relied on participant observation and extensive periods of time spent in the field, immersed in the world of one's subjects. It has since become a widely used methodological approach and mode of analysis within the field of education and the term has now expanded to include a wider set of approaches, which in my case included interviewing, typically in an unstructured or semi-structured format, and multi-sited school observations, as well as more informal visits to churches, homes, and places of work. The requisite time spent in the field has become a matter of considerable debate (Marcus 2007; Mills and Morton 2013), particularly in the case of multi-sited ethnographies (Brockmann 2011). While the techniques of recording field notes, conducting interviews, and building relationships with subjects all comprise important facets of ethnography, the enterprise is, as Geertz $(1973$, p. 6), an elaborate venture in 'thick description', that is to say, an intricately detailed depiction of the world (or a sliver of the world) of one's subjects (Parker 1963, 1989; Boo 2012; Martin 2015). As an ethnographer, this joint construction is profound; I hear the stories of my participants, and, as an active listener, I cannot help but 'give shape to what [I] hear, and in so doing, have made their stories 'into something of [my] own' (Coles 1989, p. 19).

My methodology—a multi-sited historical ethnography (Marcus 1995, p. 96)—refers not only to the fact that the study took place in two countries, but also to the fact that in each location multiple sites were visited-including several schools, homes, businesses, and churches. Marcus defines several types of multi-sited ethnographies (Marcus 1995), two of which apply to this study and are what he terms 'follow the people' and 'follow the plot, story, or allegory' (Marcus 1995, pp. 105, 109). In the first instance, 'follow the people' (Marcus 1995, p. 105), the multi-sitedness comes from tracing a single group of individuals across multiple physical spaces. This clearly applies to this study, as the movement of the Low German Mennonites is traced in the first instance from Russia to Canada in the 1870s and then from Canada to Mexico in the 1920s and ultimately back to Canada over the course of the past several decades. The second category, 'follow the plot, story, or allegory' (Marcus 1995, p. 109), is equally relevant but in this instance the focus of the plot or story is the schooling practices and how these are carried across space and time and how they are shaped by (and sometimes shape) these frequent migrations. The research process has been a dialogical process between the research questions and the data collected, what Srivastava and Hopwood describe as a negotiation between 'what the data are telling me,' and 'what I want to know' (Srivastava and Hopwood 2009, p. 78).

This project is a historical ethnography in that it draws heavily on attitudes of the past to try to inform current attitudes towards schooling held by the Low German Mennonites of Canada and Mexico. Comaroff and Comaroff (1992, p. xi) argue compellingly for the combination of history and ethnography: 'no ethnography can ever hope to penetrate beyond the surface planes of everyday life, to plumb its invisible forms, unless it is informed by the historical imagination'. Drawing on the 'historical imagination' strengthens my research in that it provides nuance and texture to the current state of schooling.

This combination of historical and anthropological approaches is underscored by Cohn and Guha (1987, p. 19), who proposes that history and anthropology share a common epistemological pursuit-they are both preoccupied with constructing and then communicating the 'other': 'one field constructs otherness in space, the other in time ... Both aim ... at explicating the meaning of actions of people rooted in one time and place, to people in another ... Both forms of knowledge entail the act of translation'. In addition to the literal act of translating much of the data-interviews, archival 
evidence, school materials-from High and Low German into English, there was the further act of translating conversations and archival data into a comprehensive whole.

The emphasis on the historical context surrounding the present situation is further underscored by Hammersley (2006, p. 5), who cautions that neglecting the wider history and context of both the group or institution and the individual is not only a methodological concern, but an ethical one as well, insofar as ignoring the historical context of the group under consideration may leave the researcher particularly vulnerable to the temptation to manipulate the data to suit current political agendas. By devoting a considerable amount of time to a historical analysis of LGM attitudes towards schooling, my work serves as a sort of corrective to ahistorical understandings of the LGM population (Hall and Kulig 2004; Saunders-Currie 2017). By appealing to the group's history to explain the current state of schooling, I hope to avoid another pitfall common among work about the Old Colony Mennonites-that of partisanship. In many cases, work about Old Colonists either glorifies them as the true protectors of the Mennonite faith, under siege by more progressive Mennonites (Plett 2001; Quiring 2006), or condemns them as pitiful souls who have lost their way (Old Colony Support 2011). The historical part of the research was based on school inspector reports from the late nineteenth and early twentieth centuries, in which non-Mennonites or non-Old Colony Mennonites, inspected Mennonite schools and submitted an annual report to the department of education (Ewert 1893, 1896, 1913; Thornton 1916). I also drew on Aeltester Isaac M. Dyck's memoir, Auswanderung von Kanada nach Mexiko (Dyck 1995) as the 'official' narrative of the migration, as recalled by one of the most influential Old Colony leaders.

Even though the Canadian province of Ontario, with its high demand for seasonal agricultural workers, has attracted the highest number of Low German Mennonites, Manitoba seemed the better site for study because of the historical roots of this group. The small prairie city in southern Manitoba around which the interviews took place was one of two hubs of original settlement by the Mennonites in the 1870s, and is located in the West Reserve, being the westernmost tract of land that the Mennonites settled in the province. It remains a predominantly Mennonite region today, with a wide range of Mennonite denominations represented in the community, with returnees from Latin America representing the most conservative faction.

I selected the Manitoba Colony, Mexico, again, primarily because it was the original Old Colony settlement site, but also because there is still a large, thriving LGM community there, with a population of approximately 21,000 people of the total 100,000 in Mexico (Giesbrecht 2018, personal communication). The Manitoba Colony in Mexico is among the most progressive colonies in Mexico, and on the more progressive end of all the colonies in Latin America. Most community members now drive vehicles, have electricity in their homes and workplaces, use cellular phones, and can speak a little Spanish. Many of these changes are relatively new. As recently as twenty or thirty years ago, community members might still have been excommunicated for some of these infractions. Although there are pockets of conservative colonies left in Mexico, the most conservative colonies are typically located in Bolivia, where no electricity and horse and buggies are still the norm (Loewen 2013). Many of the migrants to Manitoba have come from the Manitoba Colony in Mexico which provides a nice sort of symmetry for the interviews and triangulation of experience in the two locales.

Fieldwork in Canada included a dozen trips to various towns and cities in southern Manitoba to meet with and interview Old Colony Mennonites who had come from Mexico as well as those who worked with them in areas related to education. These trips ranged in length from one day to several days. In Manitoba, I interviewed families who had availed themselves of a wide variety of schooling options, including home schooling, private schooling, public schooling, and no formal schooling. In Canada, I visited three public schools with Low German Mennonite students, two independent schools, and one home school. Including a broad swath of schooling arrangements enabled me to most accurately assess the educational ideas and aspirations of the broadest spectrum of Low German Mennonites. In Mexico, I visited twelve Mennonite schools within the Manitoba Colony: five village schools, three Komitee schools, three Mennonite private schools run by those who have left the Old 
Colony church, and one Bible School that is conducted in Low German, the only such school in the world.

Subjects interviewed included individuals from the following groups: Old Colony civic leaders, teachers, current and former students, and parents of children in LGM independent, public, and home schools. In the Manitoba setting, certain interviewees had come recently from Mexico while others had been in Canada for more than 40 years. In Mexico, I included both individuals who had migrated to Canada and then returned to Mexico, and therefore had experiences with both settings, as well as those who had never left Mexico.

Setting the boundaries for participation was complicated. Initially I hoped to focus solely on the Old Colony Mennonites-one of the most conservative variants of Mennonites, but soon realized the difficulty of fixing the borders of who might qualify-did Old Colony ancestry suffice? If so, then I would fit into this group. Did they need to be active members in an Old Colony Church? Many participants were members of the Old Colony Church in Mexico but then switched to a slightly more progressive church when in Canada. Was it necessary for the participants to have been born in Mexico? Establishing the parameters was an iterative process. The families in Canada needed to be 'from' Mexico, by which I meant that their ancestors needed to have participated in the migration to Mexico from Canada and the participants needed to self-identify as LGM or work directly with them on matters related to schooling.

The demographics of participants varied widely. Interview subjects ranged from 10 to approximately 70 years old. School children who were observed ranged from five to 16 years old. Interview subjects included a roughly even split of men and women in Mexico and more women than men in Canada, as interviews tended to take place during the day when women were at home and men were working, and because my initial contacts to the community also happened to be women whose networks consisted largely of other women. Prior to embarking on this study, I had no contacts in the community and, therefore, as I began to make contacts, I relied on opportunistic sampling, that is, whomever I could find who was willing to participate and who met the above-stated criteria. As the research continued, participant recruitment became more discriminate, as I sought to 'saturate categories ... and enhance comparative analysis' (Rudestam and Newton 2014, p. 108).

In Canada, I conducted 27 interviews, ranging from one-and-a-half-hour formal interviews to several hours spread casually over several days. Typically, interviews would occur in the homes of the interviewees, at their places of work, or in a public space such as a restaurant or a café, although one was conducted via email and one via telephone. Meeting people in their homes was preferable, because it allowed me to see how they constituted their own personal space, and how they moved within it, and how they interacted with their children, some of whom were invariably home. Seeing people in their homes also gave clues as to their material wealth, their personal preferences, and often their degree of assimilation, which provided greater insight into their life choices and sometimes helped to elucidate their beliefs about schooling. For instance, in a surprising number of homes, small children played with new iPhones or handheld gaming devices while I interviewed their mothers. There were television sets in many homes, which all acted as clues to the extent to which interviewees were willing to adopt the trappings of middle-class Canadian life.

Interviews in Canada were conducted either in English or in Low German. Low German interviews were conducted with the assistance of a translator, who in this instance also served as a gatekeeper, as she worked as the liaison whose job it was to help integrate new immigrants into the public school system. She was also of Old Colony descent, and her own parents had come from Mexico. In addition to serving as a gatekeeper to the community, she also participated as an interviewee.

Over the course of April and May 2014 I travelled to the Manitoba Colony, located in the northern Mexican state of Chihuahua. While in Mexico, I visited twelve schools and interviewed close to 40 people, although many of these interviews were conducted with husbands and wives together, where the husbands did the majority of the talking. I made contacts in Mexico through acquaintances in Canada who had ties to Mennonites in Mexico. Although my grandfather was raised in Mexico 
on the Manitoba Colony, he did little to maintain ties to the conservative group after he returned to Canada as an adult in the mid-1950s. I was, therefore, delighted to be connected with relatives whom I had never met, and was welcomed into their home for the duration of my stay in Mexico.

Interviews in Mexico were either conducted in people's homes or their places of work. In the case of the school reformers and community leaders, interviews were almost all conducted in the evenings in private residences. Invariably, I would be led to the Groote Stuw, a large sitting room typically off the kitchen but separated by a closed door, and usually only used for entertaining visitors on Sunday afternoons, the time in the week designated for socializing. These rooms, like most rooms, tended to be sparsely furnished, with couches flanking the perimeter of what, by North American standards, were unusually large rooms. I would be instructed to sit on one side of the room and my interviewees, typically a husband and wife, would sit on the other. This created in many instances a considerable physical distance between my interviewees and me.

In both Canada and Mexico, I experimented with a range of interview techniques and adjusted the technique to fit the circumstance and the dynamic of each particular interview. Interviews tended towards semi-structured, although some were unstructured, depending usually on the inclination of the interviewee. Initially, I hesitated to use a recording device, heeding the warnings of others who had worked with similar groups (Hedges 1996; Johnson-Weiner 2007). I relied on a small blue moleskin notebook and a pen, and wrote frantically while people shared their stories with me. This technique created the most stilted interviews, as I struggled to take accurate notes while trying to keep a natural flow to the conversation. I experimented briefly with writing no notes, heeding Hedges's (1996, p. 32) admonition that the very sight of a pencil and notebook seemed to make her LGM interviewees uncomfortable. While this approach did make for easier conversation, I was left craving their exact words, wanting to quote directly but not being able to do so; it also left a murkier set of post-interview notes, as I struggled to recall all the specifics of a several-hours-long conversation. Finally, I decided, against the advice of other scholars in the field, to record conversations using my cellular phone (Hedges 1996; Johnson-Weiner 2007). Given the fact that Hedges' fieldwork was carried out in the mid-1990s, and Johnson Weiner's in the early 2000s, I suspected that the growing ubiquity of cellular telephone use in the intervening years had inoculated many of my interviewees to the dangers of technology use. In almost every case, interviewees agreed with little hesitation to being recorded, and where I sensed any reservation, I reverted to the use of my notebook.

After interviews or school observations were completed, I would record my impressions surrounding the interview or experience, with a description of the physical space, a description of the physical appearance and general affect of the interviewee and anything that struck me as noteworthy. These field notes have become a rich repository of images and memories that helped me to conjure the interviews as I reviewed the transcripts. These notes have contributed significantly to the 'thick' description of ethnography coined by Geertz. The details in the following note, written after visiting a teacher training meeting at a traditional Old Colony village school in Mexico, reveals how critically important the notes became as a way to recall more than simply the words of the interview:

When I arrived most students were already there. Solomon met me at the door and directed me to sit on the girls' side; because all of the teachers are men, they were seated in the boys' benches across the way. There were 10 of them in total, I would guess that they ranged from early twenties to late forties, about half were clad in overalls and I think they all wore plaid shirts. If you saw this group you wouldn't guess they were teachers; they looked like farmers. They chatted amongst themselves, all in Low German, I introduced myself awkwardly in $\mathrm{PD}$, and received mostly blank stares. For the first part they didn't look at me openly, but I could see a few looking when they thought I didn't see. Solomon opened with a few songs out of the Gesangbuch. Luckily there was a little girl's Gesangbuch in the bench and I was able to sing along. In it I found a drawing of a kitten and the foil wrapper of an Easter bunny candy pressed neatly into one of the pages. After the singing the men went back to chatting. Unfortunately I found most of it difficult if not impossible to understand. I could tell most of 
it wasn't related to schooling. They did, however, debate the names of the large numbers (i.e., a billion, etc.) and they also compared how many students each of them had. The one only had 13 and one had as many as 41 .

More visiting followed the snacks [coke, crackers and huge chunks of salami], and around 4:30 the lesson began. I could see all of the teachers take out a notebook and pen so I did the same. Solomon began a dictation and motioned for me to participate. He dictated seven sentences about 'Die Eichhoernchenjagd' and then each teacher had to spell out the word as Solomon wrote it on the board ...

There was one young teacher who started to ask me a few questions in English. He was under the impression that I was from England, which means that they had discussed me and that Solomon read the letter I left with him last week. That helped to break the ice and they started to slowly ask me more questions. I could tell they were discussing the issue of 'Buchstabieren vs. lautieren' and I was desperate to understand what they were saying. Thankfully the young teacher who spoke English (he had spent 10 summers working on farms in Ontario) asked me how I had been taught. From then on I was an active part of the discussion...

I was quite bold in my questioning, asking them what they thought of the Komitee schools [more progressive schools that were opening in the community] and if they thought that the village schools were destined to close. They, in turn, asked me what I thought of the Komitee schools and their schools and asked which group should give up ...

None of them has ever been to an Komitee school. One said that only proud people go there, that no humble person would ever go there. The one who could speak English said that they are 'fancy schools for fancy people.' I asked if they thought the DS would eventually close and 2 said yes, they would. I asked if they would become teachers there and they said no they wouldn't bc they didn't want people who weren't teachers telling them what to teach and how to teach it. I told him that sounded rather proud to me, and everyone laughed.

They said that in they are teaching what comes from heaven but that the Komitee schools are no longer Christian. It's interesting that they speak rarely of being 'Mennonite' rather of being Christlich (Christian) or Deutsch (German). For them the boundaries of the world are quite clear-Deutsch, English, Mexa, or Spanish. They think that to learn anything beyond what they teach is to learn 'worldly' things, that only lead to pride.... They also said that there is no need for Sunday School because the kids learn about 'himmlische Sachen' (heavenly things) all week so there is no need for them to go to church on Sunday.

This encounter, which lasted about two hours, represented a pivotal moment for me because, until then, I had heard the progressive voices in the community, but this more traditional perspective was missing.

Ethnography on the ground is every bit as iterative as I anticipated. Hall and Kulig (2004) note that they encountered several methodological challenges when doing research on/with Old Colony Mennonites, and while the focus of my research is on educational experiences of the community, many of the challenges were similar. In the following section, I discuss a number of the key challenges encountered in the field, particularly issues related to conducting interviews with adults and children-issues encountered by other ethnographers working with vulnerable groups (Danby and Farrell 2004; Davies 2008; Dennis 2010), the difficulty of participant observation in a multi-sited study, and conclude with a discussion of risks to my personal safety. Holding myself accountable to interviewees and being respectful of their stories, and beliefs remained a constant prioirity throughout (Law 2004; Levinson 2010).

The use of interviews is not without its difficulties, particularly when dealing with the distant past of childhood memories; however, the potential histories hold the promise of 'refining the bland messages inscribed in the official documents' (Gardner 1996, p. 144). One of the main reasons for incorporating interviews into the account of LGM schooling is that it sheds light on the actual process 
of education and people's personal attitudes and recollections-which has been largely missing from academic conversations surrounding the LGM community. One of the strengths of ethnography is its ability to use the minutiae of the specific to 'speak to large issues' (Geertz 1973, p. 23). Boo (2012, p. 249), 'I [have] no pretense that I [can] judge a whole by a sliver,' nevertheless, it is the 'complex specificness' of the ethnographer's findings that make it possible to 'think realistically and concretely' about larger concepts, such as modernization and integration (Geertz 1973, p. 23). During the interview with Wall (2014), for instance, a mother who had come alone from Mexico with her five children while her husband was incarcerated in Mexico (reportedly for participation in the drug trade), I gained a sense that for her, public schooling in Canada was far superior to what she encountered in Mexico (personal interview, 10 March 2014):

Nellie: When the children go to school, I like it when they learn, so that they are able to do something, right, they should go to school so they could do something, not, not like me, I couldn't read anything, nothing, like when they would want to get married, when they get married that they could read those so that, that they knew what it was, but I couldn't do anything ...

Nellie: Oh, my schooling, what I did there, it was nothing.

Robyn: It was nothing?

Nellie: It was just like when you would go somewhere and they babysat you, that was all. [Dry laugh]

Nellie: (Inaudible) Babysitting, babysitting was all that they did.

Other than that they don't teach anything ...

This was a sentiment shared by some but certainly not all research participants. Maria Friesen, another LGM mother in the Winkler area with several children, expressed considerably more ambivalence about her children participating in a secular school experience:

Sometimes I feel sad, I wish I could do my kids the same way my parents did me [chuckle] . . . Because I learned more respect for my parents then my, my children do for, for us [children speaking] ... The longer we stay here the more they would be, uh, like a Canadian ... I would like to see them stay the way I was taught... (Loewen 2014)

Brockmann describes one of the key challenges of multi-sited ethnography as a constant feeling of disorientation (2011). Similarly, Marcus (1995, p. 112) notes that multi-sited research requires a 'constantly mobile, recalibrating practice of positioning'. Geertz and Emerson (2001, p. 63) note that the unnerving process of 'finding our feet' defines the personal experience of conducting ethnographic fieldwork and, according to him, is never more than moderately successful, a sentiment which resonated as I reflected on my time in the field. Each new encounter required that I try to orient myself to my surroundings as quickly and unobtrusively as possible. Occasionally, it was possible to alert someone ahead of time that I wished to visit their school, but more often I would arrive, knock on the door, and explain my intentions to the teacher or director and see if he was amenable to me visiting his school. The following excerpt is from my fieldnotes, in which I described my first visit to a village school:

When I first saw the school I thought it was old, as far as I could tell initially it could have been a hundred years old. ${ }^{5}$ It was a single room, with a small house attached where the teacher and his family lived. The schoolyard was covered in gravel and had two single outhouses in the back-one for girls and the other for boys. As I discovered at lunchtime when I ventured out there was nowhere to wash my hands. There were windows down

5 I was surprised to learn later that the school was less than 15 years old. 
both of the long walls of the school, all of which are covered with billowing white curtains. For the most part the curtains remained closed throughout the day, only for a brief period, after a little girl vomited, was the one opened to expose the beautiful view of the sun and the foothills in the distance, and presumably, to allow for greater air flow. Two solitary light bulbs hung from a lightly stippled white ceiling, a stove sat in the centre of the room for heat. The walls and floor were cement, the walls painted white on top and light grey on the bottom, six rows of long low tables with child-sized benches painted a high lacquer grey, separated by a wide aisle down the centre of the room, one side for girls, the other for boys. Hooks lined the walls at the back of the class, one for the girls' wide-brimmed straw hats, and the other for boy's caps. The teacher's cowboy hat hung with the boys' caps. There was a blue plastic bucket filled with water on each side of the classroom, one for the boys and the other for the girls, each with three plastic cups for the students to share, including the little girl who was ill. There was a small platform at the front of the room, where the teacher occasionally stood, and on which his desk was set.

There were a couple of instances, with village schools in Mexico, where it was made clear that I was not welcome, and I was turned away at the door or my request to come and observe a class was denied. Generally, however, after explaining my intentions, I was invited to enter and observe. Though most of the teachers invited me to sit at the front of the room, near to where they sat or stood, I usually preferred to tuck myself into a child-sized bench in the back row, always on the girls' side, where I hoped not to disrupt. In hindsight, this may not have been the best approach, as it simply caused curious heads to turn repeatedly to inspect this unexpected visitor to their school.

Working with children added another level of complexity to the interviews-particularly in Mexico where communication was exceedingly difficult given the language barrier (Hood et al. 1996). While in the schools, I would participate in activities where possible, such as in the singing of hymns, or I would sit quietly as the students recited their work. Occasionally, I would record observations in my notebook (although I tried to do this as furtively as possible after the teacher in the first school I visited stopped the class and insisted in front of all the students that I tell him exactly what I was writing). During times when students were working independently on tasks, such as copying out passages to practice their penmanship, doing math problems, or-if it happened to be Friday afternoon - colouring or drawing, I would engage with students directly. Over the lunch hour, I would eat with either teachers or students and would join students in their play in the schoolyard, either kicking a ball with the girls, or, in the case of a more progressive Komitee school, playing volleyball with girls and boys together, under the careful gaze of the teacher, who also played along.

Fieldwork in both Canada and Mexico included both real and perceived risks to my personal safety - and the risks were not necessarily what I had anticipated at the outset. In fact, there was only a single instance where I truly felt my safety was in jeopardy, and this occurred in Canada, not Mexico. The rather exhaustive pre-fieldwork risk assessment I conducted through the University of Oxford involved only a consideration of the risks of work in Mexico-including a detailed discussion of the possibility of being kidnapped and held for ransom-a relatively common occurrence in the region during that period and related to the spike in gang-related crime. It also included recommendations from the University's safety officer that all interviews be conducted in public places such as cafés-a venue that turned out not to exist within most of the communities.

In Mexico, while the safety concerns were similar to what I had anticipated during the risk assessment, it was nevertheless a challenge practically to adhere to the 'common sense' recommendations laid out therein. During the time of my travel there, the Canadian government advised against all but essential travel to the region where the Mennonites live due to ongoing drug-related violence. It affected my route into the country, as I had to avoid the shared border with the United States, which was particularly high risk. I was advised by people familiar with the situation to avoid highways, particularly at night, and not to travel alone. While this was reasonable advice, it was difficult to heed these warnings in practice. 
My hosts lent me one of their cars, and, after escorting me to my first school via a winding path through farmers' fields- their late model car scraping the rocks on the path as I drove-they sent me out on my own. Gaining trust of community members was certainly not a given, and did not always come easily. Many Old Colonists are wary of outsiders, particularly because of aggressive evangelization from North American Mennonites. Because my hosts had recently disaffected from the Old Colony church, and had recently started their own church, they were no longer welcome in most of the places I wished to visit; therefore, I set out alone to make contacts with community members. Although the main commercial corridor is well marked by signs denoting each passing kilometer, streets off the highway are rarely marked and directions are given orally by landmarks. I spent a lot of time visiting with people on their yards as I pulled over to ask directions while trying to navigate my way to schools and homes throughout a colony that spans dozens of kilometers of undulating barrenness checkered with tidy homes and farms, small oases of productivity.

In Mexico, under the guidance of my gatekeepers there, I determined not to seek out a translator or a local guide, rather, I travelled alone and conducted interviews without the assistance of an intermediary. I was advised by my initial contacts in the community that a translator would compromise the integrity of the responses I might receive, because of social pressure to represent things in a certain way in front of other community members. To be sure, a translator would have made things easier, as the interviewees could have used more Low German, their primary language of communication. However, having to communicate in a mix of High German and Low German created a shared vulnerability-my Low German competence is very low and my interviewees almost without exception expressed shame about their limited fluency in High German.

Perhaps the risk, if any, that I felt most acutely was that of being a woman alone among men who were unknown to me. There is an emerging body of research discussing the risks posed to researchers in the field (Kenyon and Hawker 1999; Paterson et al. 1999) and increasingly on women conducting fieldwork (Sharp and Kremer 2006; Fry 2013). The overwhelming majority of interviewees in Mexico were men-teachers and community leaders-and I was a woman alone, often meeting alone with a man or groups of men whom I had never met-with no one knowing my whereabouts. For instance, by attending the village teachers' meeting I risked being alone in a remote location with a group of unknown men, but this exchange was one of the most enlightening of the entire research journey and became pivotal to my understanding of LGM schooling. Because most of the interviewees were men, it also meant that they were away working all day and were only free to meet in the evenings. That meant that I had no choice but to ignore the advice to avoid the highways after dark. And though many interviewees recounted stories of neighbours and relatives being kidnapped or robbed at gunpoint, at no point did I feel like my own safety was in jeopardy. As the mother of an infant son at the time, the safety warnings added another dimension of complication. In a less volatile environment, I would have brought my son along; however, given the safety concerns about the region, I decided against this. Leaving him behind with other family members limited the time I was able to spend in the field.

In Canada, I had to contend with safety concerns of another kind-the threat of the natural environment. Winnipeg, recognized as one of the coldest cities in the world, was experiencing the coldest winter in over a hundred years (Turner 2014). Because the geographic area of research was located several hours from my house, this required driving on remote snow-covered highways through snow storms to meet interviewees. The fact that this is an unavoidable part of life on the Canadian prairies makes it no less terrifying. In fact, one of the first people I interviewed for this project, David Friesen, an early school reformer from Mexico, was killed in January of 2018 in a motor vehicle incident in winter driving conditions in Manitoba.

On one particular instance, in January of 2014, I had travelled to southern Manitoba to conduct a round of interviews. I stayed at a hotel in Winkler and planned to spend a couple of days travelling to surrounding communities conducting interviews. The hotel did not have an outlet in the parking lot to plug in the block heater overnight on my aging SUV so when I went to start the truck in the morning, it simply refused to cooperate after sitting out overnight in $-45^{\circ} \mathrm{C}$ temperatures. Not wanting to miss 
the interviews, I quickly called a car rental company and rented their least expensive car. As soon as I left town, I regretted my decision-the car was not up to the challenge of a prairie blizzard, and neither was I. I clutched the steering wheel and crept along the barren stretch of road between towns, hazard lights flashing into a wall of white and praying that I would manage to 'keep it between the ditches' as my Mennonite grandfather would say. Eventually I did arrive at the home of my first interviewee-frazzled, late, and relieved to be alive. She was shocked to see that I had ventured out in these conditions; she had simply assumed that I would not be making the trip. As I settled in for a discussion, Helen shared with me the story of her own much more harrowing journey of coming to Canada in the 1970s by bus as a young family, hoping for a more economically stable future for their children. Today, her daughter possesses a Master's degree and is a strong advocate for the public school system, whereas her son and his wife homeschool their children as a way to insulate them from what they regard as the state's secularizing agenda.

While the LGM migration experience is certainly unique in its particularities, it is but one of many migrations to Canada, a receiving nation which prides itself on its welcoming and inclusive stance towards immigrants (Good Gingrich 2016), although the voluntary social exclusion practiced by Low German Mennonite migrants complicates the trope of grateful immigrant, eager to integrate into Canadian society (Good Gingrich 2016).

When the Mennonites came to Manitoba in the 1870s, it was with the goal of living out their lives quietly and educating their children in a way that was consistent with their faith and worldview (Epp 1974). Government intervention made this increasingly less tenable and resulted in a mass exodus to Mexico. Over time, tens of thousands of the descendants of the original emigrants have made return migrations to Canada, where they continue to struggle with the government's secular educational agenda-some resisting by keeping their children out of school altogether and others participating reluctantly.

As an ethnographer, I feel a duty to my participants to share this little-known story, and to place it within the proper historical context. The multi-sitedness required a constant renegotiation of my position vis-à-vis my research participants, but in the end helped to establish a fuller portrait of LGM schooling. It is my hope that by shedding light on the iterative, messy process, and by discussing both the real and perceived security risks attendant with conducting research, that others working with other communities of faith may gain some insight that may be applicable across disciplines. This article also highlights the complicated and often fraught relationship between academic researchers and the institutions which provide ethics and security approval and support for their work. Drawing on a range of methods-interviewing, participant observation, and archival analysis-in a variety of contexts: in Canada and Mexico, in homes and in schools-has enabled me to most effectively elucidate the attitudes among my research subjects towards schooling and to clarify their beliefs about the purpose that schooling serves.

Collecting the data required nimbleness and reflexivity on my part-a willingness to position my project and myself in such a way that was comprehensible to my research subjects. My limited Low German language skills and relative outsider status created a vulnerability that necessitated that I frequently reposition myself in relation to my research subjects, emphasizing a shared profession and common ancestry. Ultimately, my own vulnerability diminished the power imbalance that often exists between researcher and researched, both with children and with adults, and fostered a safer space which led to richer and, I suspect, more open conversations with my interviewees. Working through a gatekeeper brought challenges of how to establish rapport with subjects while working through a translator. The fact that in Canada the translator was also the representative of the school-the institution about which I wished to interview my subjects-complicated matters further. Working without a translator, as I did in Mexico, limited my ability to converse freely with some subjects, but fostered a more open atmosphere because of the lack of other community representatives. Building on Coles's (1989) and Geertz's (1973) notions of the interview as a co-constructed story, as a conversation, 
facilitated the telling of this story and enabled me to 'grasp and to render' (Geertz 1973) issues coalescing around the schools.

As LGM migrants return to Canada to reclaim their lost citizenship, it is often with a sense of ambivalence towards schooling and the implications that accompany each particular schooling option. As one piece of the patchwork quilt that is Canadian multiculturalism, the LGM example highlights many of the issues attendant with integrating newcomers (Sweet 1997). And while Mennonite migrants are not generally considered a threat to national security, their general lack of assimilation into school culture and wider culture raises important questions about the extent to which newcomers ought to be accommodated. And as long as the Mennonites maintain their threads of connection across borders, carrying ideas and experiences of schooling back and forth between Canada and Mexico, 'the schools question,' as it was known in the early twentieth century, will be one which needs to be continually negotiated.

The powerful and relatively unknown story of Low German Mennonite schooling in Canada is a compelling case of a minority group using education to preserve its religious and linguistic boundaries vis-à-vis the dominant culture. Nearly 100 years after the 1922 exodus to Mexico, tension over schooling continues, as it seems that many Mennonites still do not comply with laws related to education. Contemporary schooling practices in both Canada and Mexico demonstrate that it is their history of transnationalism and consequent lack of loyalty to a particular nation state that characterizes their attitude towards schooling. As citizens of a godly kingdom, not an earthly one, attempts to assimilate and inculcate in them the values of a particular nation have been, and often continue to be, resisted.

Funding: This research was funded by doctoral research fellowships through the P.E. Trudeau Foundation and the Social Sciences and Humanities Research Council of Canada, grant number 752-2015-0107.

Conflicts of Interest: The author declares no conflict of interest.

\section{References}

Anderson, Benedict. 1983. Imagined Communities: The Origin and Spread of Nationalism. London and New York: Verso. Boo, Katherine. 2012. Behind the Beautiful Forevers. New York: Random House LLC.

Brockmann, Michaela. 2011. Problematizing short-term participant observation and multi-method ethnographic studies. Ethnography and Education 6: 229-43. [CrossRef]

Bruno-Jofre, Rosa, ed. 1993. Issues in the History of Education in Manitoba: From the Construction of the Common School to the Politics of Voices. Lewiston: The Edwin Mellen Press.

Old Colony Support. 2011. Called to Mexico: Bringing Hope and Literacy to the Old Colony Mennonites. Walnut Creek: Carlisle Printing.

Cohn, Bernard S., and Ranajit Guha. 1987. An Anthropologist among the Historians and Other Essays. Oxford: Oxford University Press.

Coles, Robert. 1989. The Call of Stories: Teaching and the Moral Imagination. New York: Houghton, Mifflin and Company. Comaroff, John, and Jean Comaroff. 1992. Ethnography and the Historical Imagination. Boulder: Westview Press, pp. 3-49.

Crocker, Wendy A. 2013. Telling Tales Out of School: Principals' Narratives of the Relationship between School Literacy and the Home Literacy Practices of a Minoritized Culture. Ph.D. dissertation, The University of Western Ontario, London, ON, Canada.

Danby, Susan, and Ann Farrell. 2004. Accounting for young children's competence in educational research: New perspectives on research ethics. Australian Educational Researcher 31: 35-50. [CrossRef]

Davies, Hayley. 2008. Reflexivity in Research Practice: Informed Consent with Children at School and at Home. Available online: http:/ / www.socresonline.org.uk/13/4/5.html (accessed on 18 December 2018).

Dennis, Barbara. 2010. Ethical dilemmas in the field: The complex nature of doing education ethnography. Ethnography and Education 5: 123-27. [CrossRef]

Dyck, M. Isaak. 1995. Auswanderung von Kanada nach Mexiko ano 1922, 3rd ed. Mexico City: Gedruckt bei Imprenta Colonial, vols. 1-2.

Ens, Adolf. 1994. Subjects or Citizens? The Mennonite Experience in Canada, 1870-1925. Ottawa: University of Ottawa Press, vol. 2. 
Epp, Frank. H. 1974. Mennonites in Canada, 1786-1920: The History of a Separate People. Toronto: Macmillan of Canada, vol. 1.

Evans-Pritchard, Edward Evan. 1940. The Nuer. Oxford: Clarendon.

Ewert, Henry H. 1893. School Inspector Report, 1893, Report of the Department of Education, Year Ending Dec 31, 1893, Accession Fonds, 2013-053. Winnipeg: Mennonite Heritage Centre Archives.

Ewert, Henry H. 1896. Cameron, JD Report of the Department of Education for the Year Ending Dec 31, 1896. Sessional Papers, (No. 18). 1897. Accession Papers, 2013-053. Winnipeg: Mennonite Heritage Centre Archives.

Ewert, Henry H. 1913. Manitoba Free Press, February 12, 1913, in Accession Fonds, 2013-053. Winnipeg: Mennonite Heritage Centre Archives.

Francis, Emerich K. 1955. Search of Utopia: The Mennonites of Manitoba. Steinbach: Crossway Publications.

Fry, Lincoln. 2013. Gender and dangers inherent in fieldwork. Gender and Behaviour 11: 5474-85.

Gardner, Philip. 1996. The giant at the front: Young teachers and corporal punishment in inter-war elementary schools. History of Education 25: 141-63. [CrossRef]

Gearon, Liam. 2013. The counter terrorist classroom: Religion, education, and security. Religious Education 108: 129-47. [CrossRef]

Geertz, Clifford. 1973. The Interpretation of Cultures: Selected Essays. Arizona: Basic Books, vol. 5019.

Geertz, Clifford, and Robert M. Emerson. 2001. Thick description: Toward an interpretive theory of culture. In Contemporary Field Research. Long Grove: Waveland Press.

Ghosh, Ratna, Ashley Manuel, W. Y. Alice Chan, Dilmurat Mahmut, and Mehdi Babaei. 2016. Education and Security: A Global Literature Review on the Role of Education in Countering Violent Religious Extremism. Montreal: McGill University Press.

Giesbrecht, Kennert. 2018. Winnipeg, MB, Canada. Personal communication.

Good Gingrich, Luann. 2016. Out of Place: Social Exclusion and Mennonite Migrants in Canada. Toronto: University of Toronto Press.

Gregor, Alexander, and Keith Wilson. 1984. The Development of Education in Manitoba. Dubuque: Kendall/Hunt Publishing.

Hall, Barry L., and Judith Kulig. 2004. Kanadier Mennonites: A case study examining research challenges among religious groups. Journal of Qualitative Research 14: 359-68. [CrossRef] [PubMed]

Hammersley, Martyn. 2006. Ethnography: Problems and prospects. Ethnography and Education 1: 3-14. [CrossRef]

Hedges, Kelly Lynn. 1996. "Plautdietsch" and "Huuchdietsch" in Chihuahua: Language, Literacy, and Identity among the Old Colony Mennonites in Northern Mexico. Doctoral dissertation, Yale University, New Haven, CT, USA. Available online: http:/ / search.proquest.com/docview/304306887?accountid=13042(304306887) (accessed on 18 December 2018).

Hood, Suzanne, Peter Kelley, and Berry Mayall. 1996. Children as research subjects: A risky enterprise. Children $\mathcal{E}$ Society 2: 117-28.

Janzen, William. 1990. Limits on Liberty: The Experience of Mennonite, Hutterite, and Doukhobor Communities in Canada. Toronto: University of Toronto Press.

Johnson-Weiner, Karen. 2007. Train up a Child: Old Order Amish E Mennonite Schools. Baltimore: Johns Hopkins University Press.

Kenyon, Elizabeth, and Sheila Hawker. 1999. 'Once would be enough': Some reflections on the issue of safety for lone researchers. International Journal of Social Research Methodology 2: 313-27. [CrossRef]

Krahn, Cornelius, and H. Leonard Sawatzky. 1990. Old Colony Mennonites. Global Anabaptist Mennonite Encyclopedia Online. Available online: http://www.gameo.org/encyclopedia/contents/O533ME.html (accessed on 31 May 2013).

Law, John. 2004. After Method: Mess in Social Science Research. London: Psychology Press.

Levinson, Martin P. 2010. Accountability to research participants: Unresolved dilemmas and unravelling ethics. Ethnography and Education 5: 193-207. [CrossRef]

Loewen, Royden. 2013. Village among Nations: "Canadian" Mennonites in a Transnational World. Toronto: University of Toronto Press.

Loewen, Bernie. 2014. Winnipeg, MB, Canada. Personal communication.

Loewen, Royden. 2015. A Village Among the Nations: Low German Migrants and the Idea of Transnationalism in the History of Mennonites in Canada. Available online: https:/ / uwaterloo.ca/grebel/publications / conrad-grebelreview/issues/winter-2015/village-among-nations-low-german-migrants-and-idea (accessed on 18 December 2018). 
Malinowski, Bronislaw. 1922. Argonauts of the Western Pacific. New York: Dutton.

Manitoba Schools Act. 2013. Manitoba Education. Available online: http://www.edu.gov.mb.ca/k12/schools / ind/non_fund_ind.html (accessed on 1 March 2013).

Marcus, George E. 1995. Ethnography in/of the world system: The emergence of multi-sited ethnography. Annual Review of Anthropology 24: 95-117. [CrossRef]

Marcus, George E. 2007. How short can fieldwork be? Social Anthropology 15: 353-57. [CrossRef]

Martin, Wednesday. 2015. Primates of Park Avenue: A Memoir. New York: Simon and Schuster.

Mead, Margaret. 1928. Coming of Age in Samoa. New York: Morrow.

Mills, David, and Missy Morton. 2013. Ethnography in Education. Thousand Oaks: SAGE.

Orsi, Robert. 1997. Everyday Miracles: The Study of Lived Religion. In Lived Religion in America: Towards a History of Practice. Edited by David D. Hall. Princeton: Princeton University Press.

Parker, Tony. 1963. The Unknown Citizen. London: Faber \& Faber.

Parker, Tony. 1989. Bird, Kansas. New York: Knopf.

Paterson, Barbara L., David Gregory, and Sally Thorne. 1999. A Protocol for Researcher Safety. Qualitative Health Research 9: 259-69. [CrossRef] [PubMed]

Peters, Jake. 1985. Mennonite Private Schools in Manitoba and Saskatchewan, 1874-1925. Historical Series II. Steinbach: Mennonite Heritage Village.

Plett, Delbert. 2001. Old Colony Mennonites in Canada, 1875 to 2000. Steinbach: Crossway Publications.

Quiring, David Menno. 2006. The Mennonite Old Colony Vision: Under Siege in Mexico and the Canadian Connection. Wheaton: Crossway Publications.

Ramirez, Francisco, and John Boli. 1987. The political construction of mass schooling: European origins and worldwide institutionalization. Sociology of Education 60: 2-17. [CrossRef]

Rudestam, Kjell Erik, and Rae R. Newton. 2014. Surviving Your Dissertation: A Comprehensive Guide to Content and Process. Thousand Oaks: Sage Publications.

Saunders-Currie, Avril. 2017. Alternative Education for Low German Mennonite Students: A Negotiation of Education for Equity and Inclusion. Ph.D. dissertation, University of Toronto, Toronto, ON, Canada.

Leonard, Sawatzky Harry. 1971. They Sought a Country: Mennonite Colonization in Mexico. Berkeley: University of California Press.

Schmiedehaus, Walter. 1982. Die Altkolonier-Mennoniten in Mexiko. Steinbach: CMBC Publications.

Sharp, Gwen, and Emily Kremer. 2006. The safety dance: Confronting harassment, intimidation, and violence in the field. Sociological Methodology 36: 317-27. [CrossRef]

Srivastava, Prachi, and Nick Hopwood. 2009. A Practical Iterative Framework for Qualitative Data Analysis. International Journal of Qualitative Methods 8: 76-84. [CrossRef]

Stambach, Amy. 2000. Lessons from Mount Kilimanjaro: Schooling, Community, and Gender in East Africa. London: Routledge.

Sweet, Lois. 1997. God in the Classroom: The Controversial Issue of Religion in Canada's Schools. Toronto: McLelland and Stewart.

Thornton, Robert S. 1916. Minister of Education, Address to the Manitoba Legislature, Accession Fonds, 2013-053. Winnipeg: Mennonite Heritage Centre Archives.

Tönnies, Jose. 2001. Community and Civil Society. Cambridge: Cambridge University Press.

Turner, Randy. 2014. City's Worst Winter Since 1898 Canada's National Forecaster Has Hard, Cold Facts to Prove It. Available online: https:/ / www.winnipegfreepress.com/local/citys-worst-winter-since-98----1898254004961.html (accessed on 18 December 2018).

Urry, James. 2006. Mennonites, Politics, and Peoplehood: Europe, Russia, Canada, 1525 to 1980. Winnipeg: University of Manitoba Press.

Urry, John. 2000. Sociology beyond Societies: Mobilities for the Twenty-First Century. London: Routledge.

Weber, Max. 1921. Economy and Society. Edited by G. Roth and C. Wittich. Berkeley: University of California Press. Wall, Nellie. 2014. Personal Interview. Winkler, MB, Canada, March 10.

(C) 2019 by the author. Licensee MDPI, Basel, Switzerland. This article is an open access article distributed under the terms and conditions of the Creative Commons Attribution (CC BY) license (http:/ / creativecommons.org/licenses/by/4.0/). 